\title{
Identification of Groundwater's Type in Sarabium Archaeological Site - Atfiyah - Egypt and Its Microbiological Effect
}

\author{
Rabea Radi Abdel Kader, Abdel Hamid Kafafy, Shaimaa Sayed Mohamed El-Sayed* \\ Restoration Department, Faculty of Archaeology, Cairo University, Giza, Egypt
}

Email address:

Egyptianconservators2013@gmail.com (S. S. M. El-Sayed)

*Corresponding author

\section{To cite this article:}

Rabea Radi Abdel Kader, Abdel Hamid Kafafy, Shaimaa Sayed Mohamed El-Sayed. Identification of Groundwater's Type in Sarabium Archaeological Site - Atfiyah - Egypt and Its Microbiological Effect. International Journal of Archaeology. Vol. 4, No. 5, 2016 , pp. 67-77. doi: $10.11648 /$ j.ija.20160405.13

Received: June 19, 2016; Accepted: July 30, 2016; Published: August 29, 2016

\begin{abstract}
Sarabium archaeological site locates in Atfiyah center - Egypt, it belonged to $26^{\text {th }}$ dynasty, the site suffers from the groundwater which affects badly on the deterioration of the building materials there, many microorganisms grow on lime stone carved coffins and ruins, they produce organic compounds which react with lime stone and turn to soluble salts, this is called biological weathering of the lime stone. This research will include the identification of the ground water's type and the microorganisms grown, their visible effect.
\end{abstract}

Keywords: Sarabium Archaeological Site, Ground Water, Microorganisms, Limestone

\section{Introduction}

Sarabium archaeological site locates in Atfiyah center Giza governorate, Apis bull buried in many tombs which Called "Sarabium "like Saqqara Sarabium site but Atfiyah's Sarabium is for the burial of Hathur cow which was the main goddess of Atfiyah's center in this time, the site contains of many tombs for Hathur cow from the $26^{\text {th }}$ dynasty [1]. The site suffers from the existence of groundwater in the carved limestone' coffins because of the short distance between the site and the fields around it (100 meter approx.), the site is lower than the surrounded area and the groundwater aggregates inside the coffins. The groundwater includes some salts which arise in the building materials with capillary system and destroy them by growing inside and make stresses, also the groundwater contains microorganisms which produce organic compounds, these compounds react with building materials and turn them into soluble materials. The result is the loss of the building materials in the end.

\section{Materials and Methods}

\subsection{The Ground Water's Analysis}

We took water's sample from one of the limestone's coffins to identify it, the sample analyzed in Water testing central laboratories - Drinking Water and Sanitation Company in Fayoum governorate - Ministry of Housing and Utility Egypt. Figure (1-3).

\subsection{The Analysis of Limestone Ruins}

A sample of limestone was analyzed by X - Ray Diffraction (XRD) to identify its components and examined by Scanning Electron Microscope (SEM) to study the surface; also the sample was analyzed by EDAX (Energy dispersive $\mathrm{x}$-ray spectroscopy) to know its mineral elements. Figure (4-6).

\subsection{Identification of the Limestone's Ruins Mortar}

A sample of mortar was analyzed by X- Ray Diffraction (XRD) to identify its components, examined by Scanning Electron Microscope (SEM) to study the surface, and 
examined by Polarizing microscope to identify its components. Figure (7-9).

\subsection{The Analysis of Mud Bricks Ruins}

A sample of mud bricks was analyzed by X-Ray Diffraction (XRD) to know its components, also examined by Scanning Electron Microscope (SEM) to study the entire texture of the surface with different magnification power, and the Elemental analysis of the sample with EDAX. Figure (10-12).

\subsection{Identification of Salts in the Building Materials}

A sample of salts' flakes from the limestone ruins was taken and analyzed by X- Ray Diffraction (XRD), examined by Scanning Electron Microscope (SEM) and analyzed by
(EDAX). Figure (13-15)

\subsection{Identification of the Grown Weeds in the Site}

A sample of dominant plants or weeds which grew intensively in the site was taken and identified with the plants laboratory in the Agricultural and Biological Research Division - National Research Center - Egypt. Figure (16-18).

\subsection{Identification of the Microbiological Effect of the Groundwater}

From the water's analysis, we identify the microbiological effect of groundwater on the limestone'

Coffins and ruins. Figure (19).

\begin{tabular}{|c|c|c|c|c|c|c|c|c|}
\hline Inorganic Parameter & Unit & 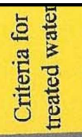 & 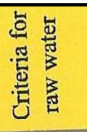 & 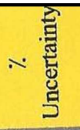 & $\stackrel{8}{9}$ & อิ & $\begin{array}{l}\text { Ground water } \\
\text { sample }\end{array}$ & \\
\hline ample Code & & & & & & & $S / W 02 / 09 / 13 / 200$ & \\
\hline 1 Temperature & $\begin{array}{l}\mathrm{C}^{0} \\
\mathrm{ppm}\end{array}$ & & $>5$ & & & & NA & \\
\hline 2 Res.Chlorine & $\mathrm{ppm}$ & $\begin{array}{c}5 \\
6.5-8.5\end{array}$ & & & 0.108 & & NA & \\
\hline $\begin{array}{ll}3 & \mathrm{pH} \\
4 & \text { Total dissolved solids }\end{array}$ & & $\begin{array}{l}6.5-8.5 \\
1000\end{array}$ & $7-8.5$ & 0.85 & 0.108 & 0.032 & $\begin{array}{l}7.89 \\
1609\end{array}$ & \\
\hline $\begin{array}{ll}4 & \text { Total dissolved solids } \\
5 & \text { Nitrate }\left(\mathrm{NO}_{3}\right)\end{array}$ & $\begin{array}{l}\mathrm{ppm} \\
\mathrm{ppm}\end{array}$ & $\begin{array}{c}1000 \\
45\end{array}$ & $>45$ & 4.4 & 0.126 & 0.011 & $\begin{array}{l}1609 \\
\mathrm{AC}\end{array}$ & \\
\hline $\begin{array}{ll}5 & \text { Nitrate }\left(\mathrm{NO}_{3}\right) \\
6 & \text { Total alkalinity }\end{array}$ & ppm & 45 & $20-150$ & 1.8 & 7.338 & 4.427 & $\begin{array}{l}A C \\
99.2\end{array}$ & \\
\hline $\begin{array}{l}6 \text { Total alkalinity } \\
7 \text { Total hardness }\end{array}$ & ppm & 500 & & 3.24 & 3.706 & 1.112 & $\begin{array}{l}99.2 \\
802.4\end{array}$ & \\
\hline $\begin{array}{ll}7 & \text { Total hardness } \\
8 & \text { Permanent hardness }\end{array}$ & $\mathrm{ppm}$ & & & & & & 703.2 & \\
\hline $\begin{array}{ll}8 & \text { Permanent hardness } \\
9 & \text { Temporary hardness }\end{array}$ & $\mathrm{ppm}$ & & & & & & 99.2 & \\
\hline $\begin{array}{l}9 \text { Temporary hardness } \\
10 \text { Calcium hardness }\end{array}$ & $\mathrm{ppm}$ & 350 & & & & & 729.6 & \\
\hline $\begin{array}{l}10 \text { Calcium hardness } \\
11 \text { Magnesium hardness }\end{array}$ & ppm & 150 & & & & & 72.8 & \\
\hline $\begin{array}{l}11 \text { Magnesium hardness } \\
12 \text { Chlorides }\end{array}$ & $\mathrm{ppm}$ & 250 & & 4.1 & 0.486 & 0.166 & 142.19 & \\
\hline $\begin{array}{l}12 \text { Chlorides } \\
13 \text { Fluoride }\end{array}$ & $\mathrm{ppm}$ & 0.8 & $<0.5$ & & 0.011 & 0.004 & 1.117 & \\
\hline $\begin{array}{l}13 \text { Fluoride } \\
14 \text { Sulfate }\end{array}$ & $\mathrm{ppm}$ & 250 & $<200$ & 12.9 & 0.091 & 0.031 & 1000.09 & \\
\hline $\begin{array}{l}14 \text { Sulfate } \\
15 \text { Color }\end{array}$ & $\mathrm{Pt} / \mathrm{Co}$ & $<5$ & $<100$ & & & & NA & \\
\hline $\begin{array}{l}15 \text { Color } \\
16 \mathrm{CO}_{3}\end{array}$ & $\mathrm{ppm}$ & & & & & & NA & \\
\hline $17 \mathrm{HCO}_{3}$ & $\mathrm{ppm}$ & & $20-150$ & 1.8 & 0.597 & 1.989 & NA & \\
\hline $18 \mathrm{Po}_{4}$ & ppm & & & & & & NA & \\
\hline 19 Total phosphours & $\mathrm{ppm}$ & & & & & & NA & \\
\hline 20 Ammonia $\left(\mathrm{NH}_{3}\right)$ & $\mathrm{ppm}$ & 0.5 & $>0.5$ & & & & NA & \\
\hline$A C$ : The parameter accre & & & NA: N & Not ane & alyzed & & - & ND: Not detected \\
\hline
\end{tabular}

Figure 1. Shows the inorganic parameter of the ground water sample.

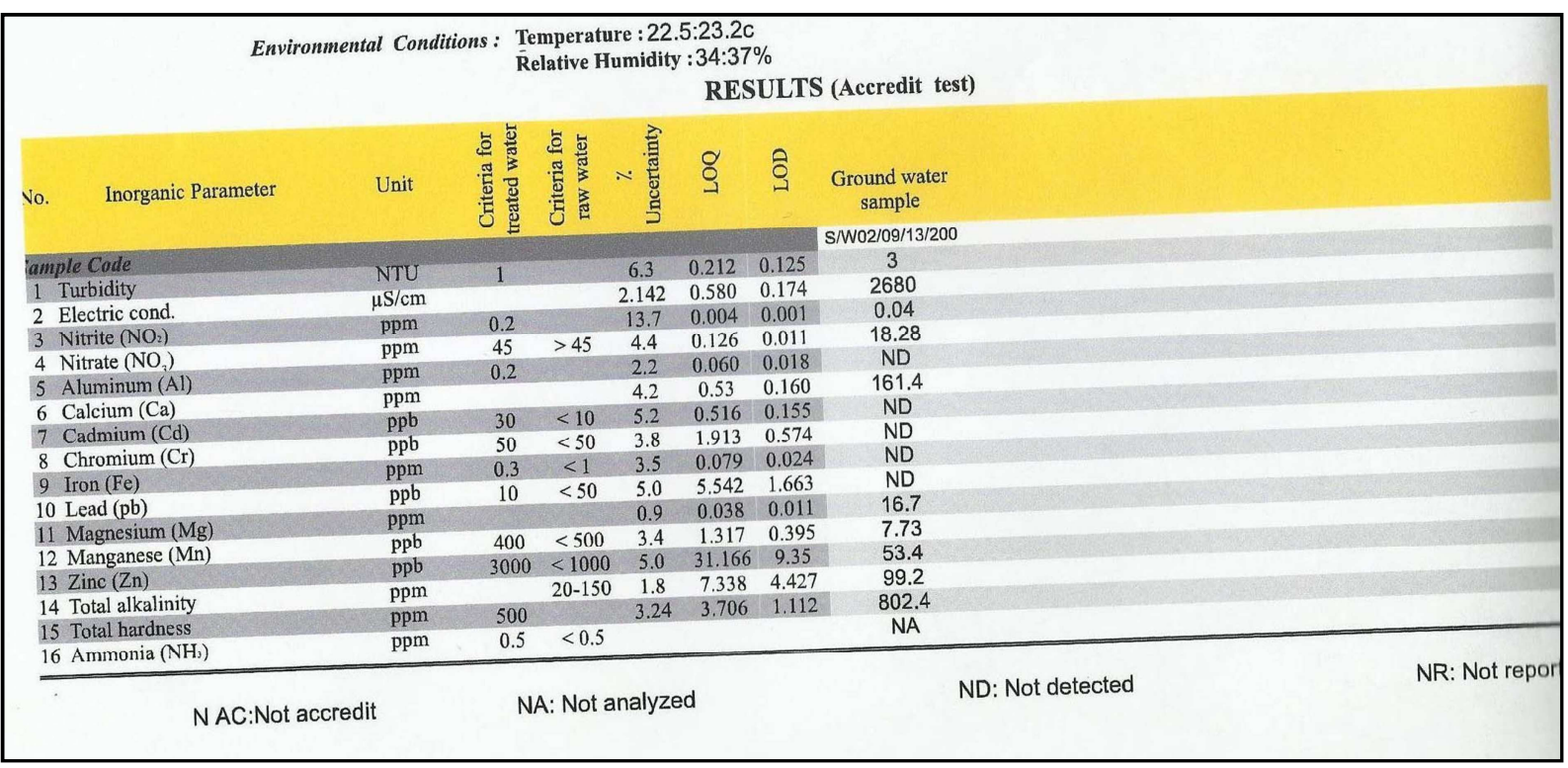

Figure 2. Also shows the inorganic parameter of the groundwater sample. 


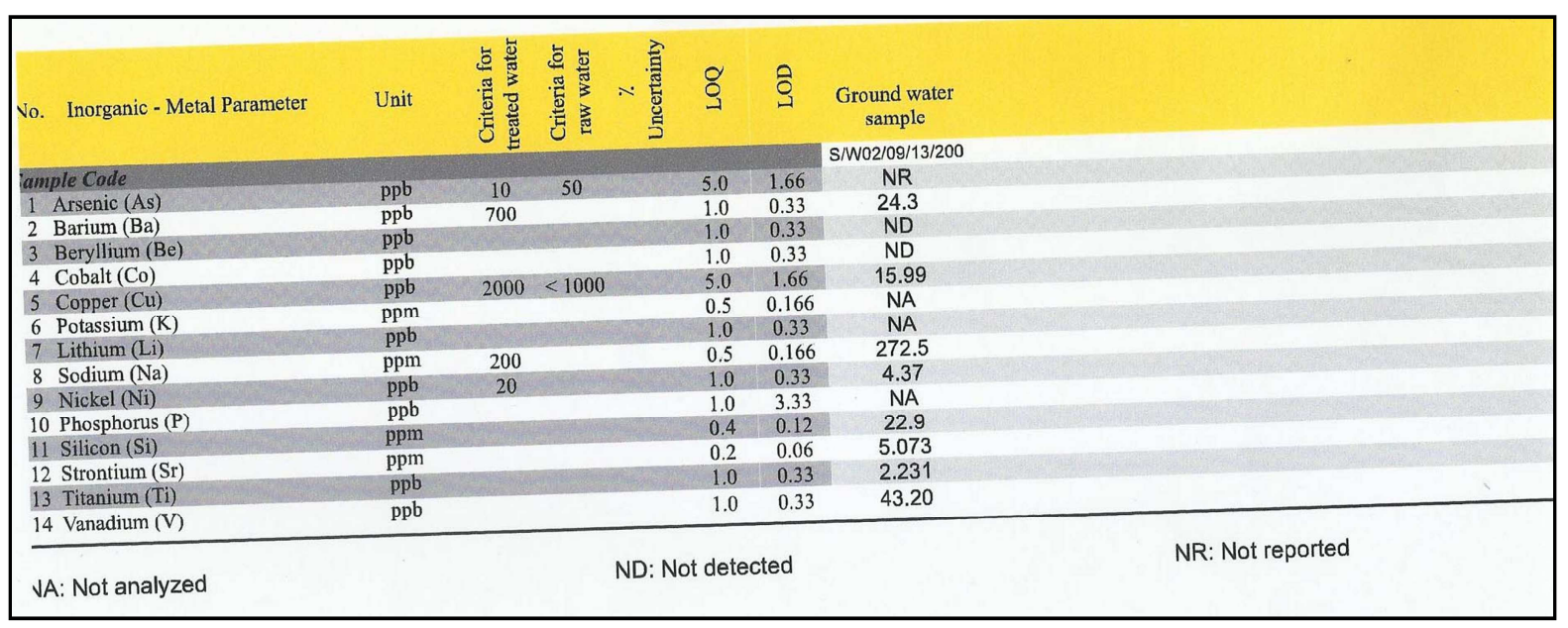

Figure 3. Shows the metal parameter of the groundwater sample.

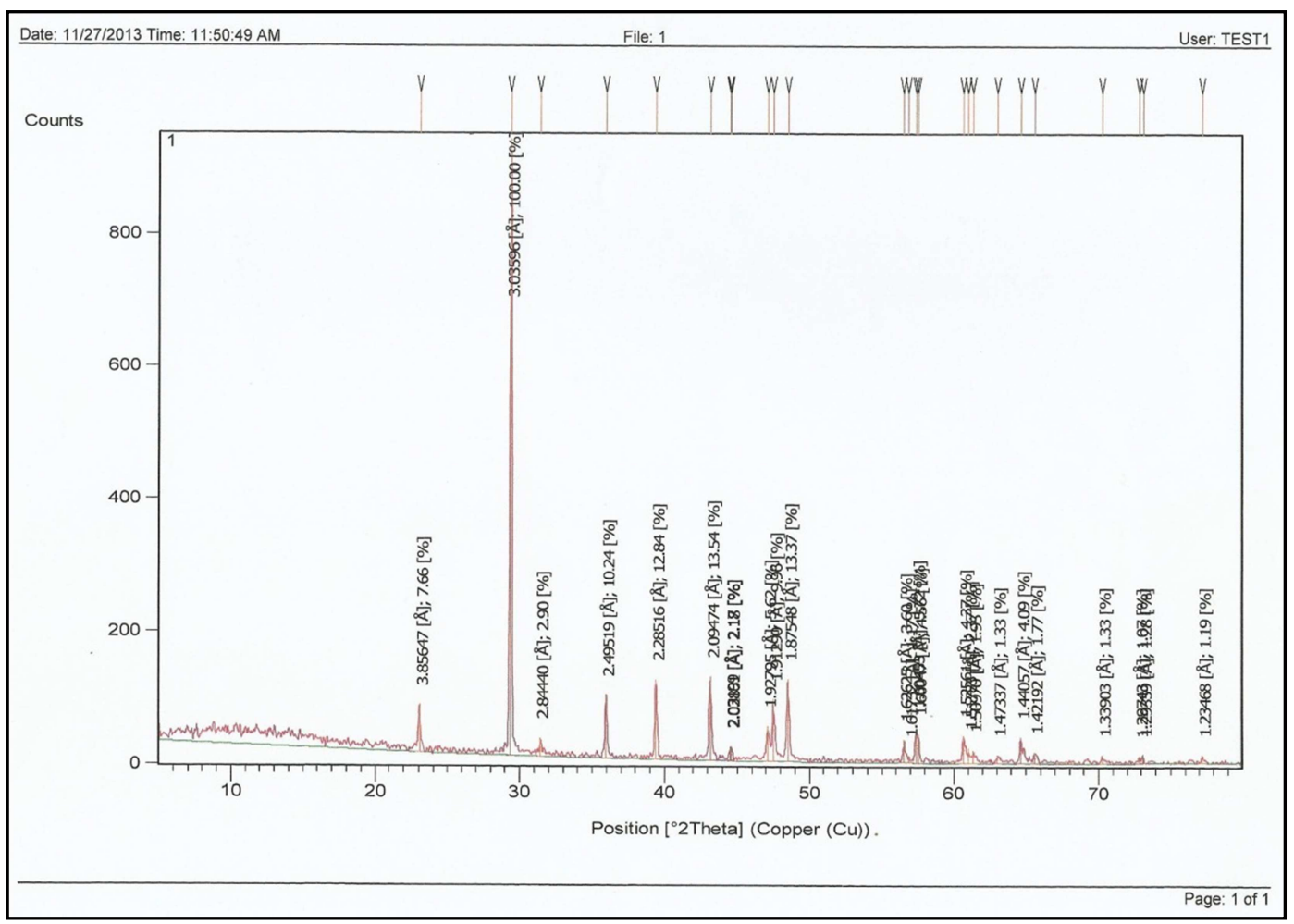

Figure 4. Shows the XRD pattern of the limestone's sample.

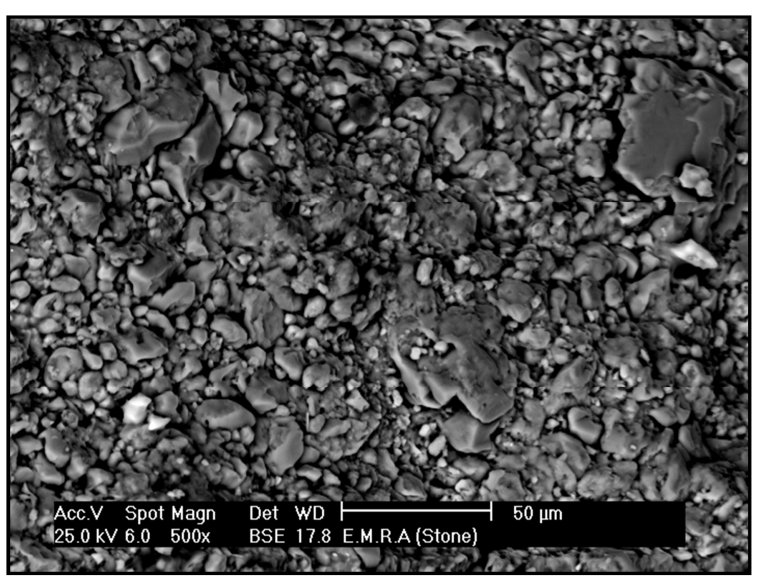

Figure 5. The SEM examination of the limestone's sample surface. 


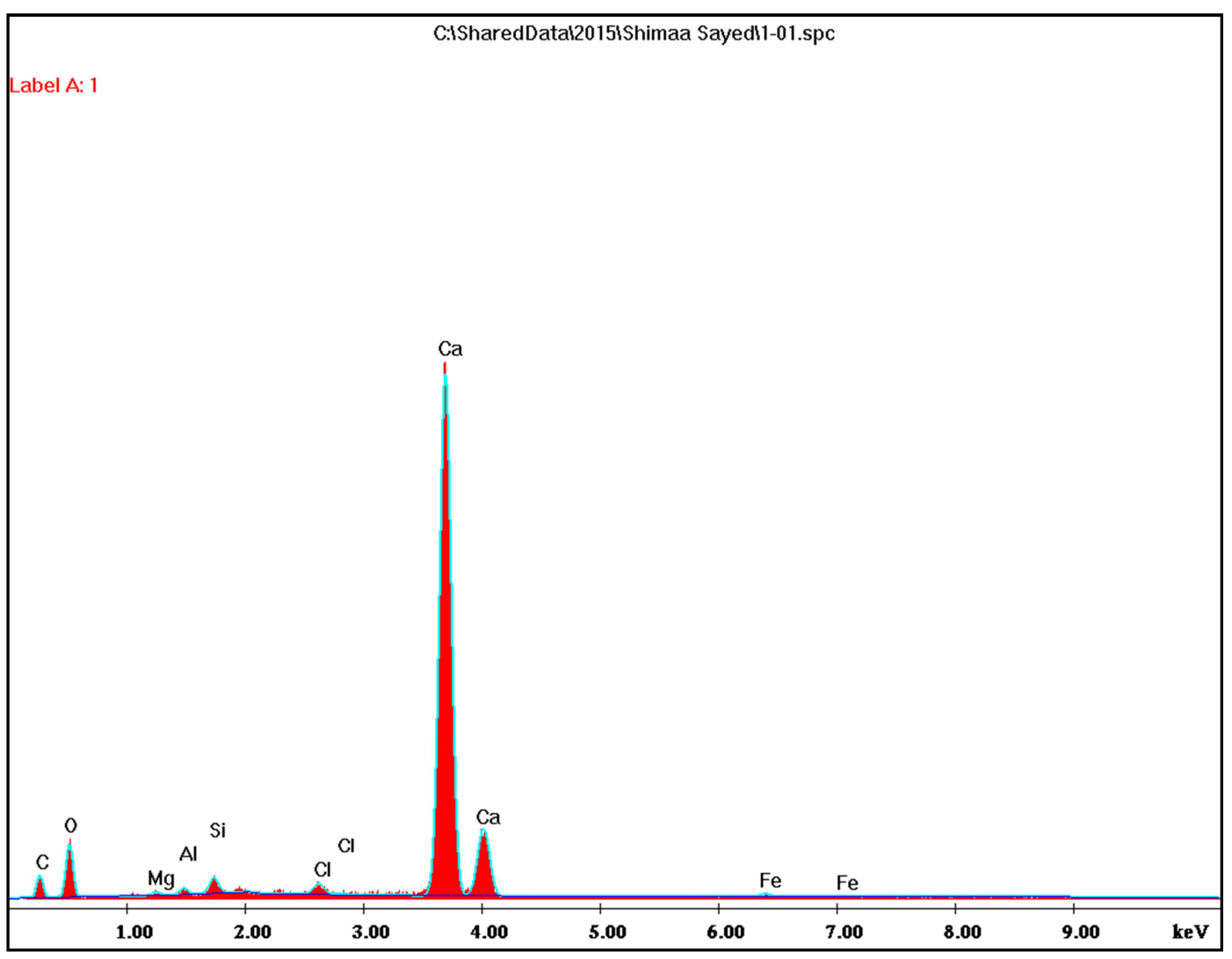

Figure 6. Shows the EDAX analysis of the limestone's sample.

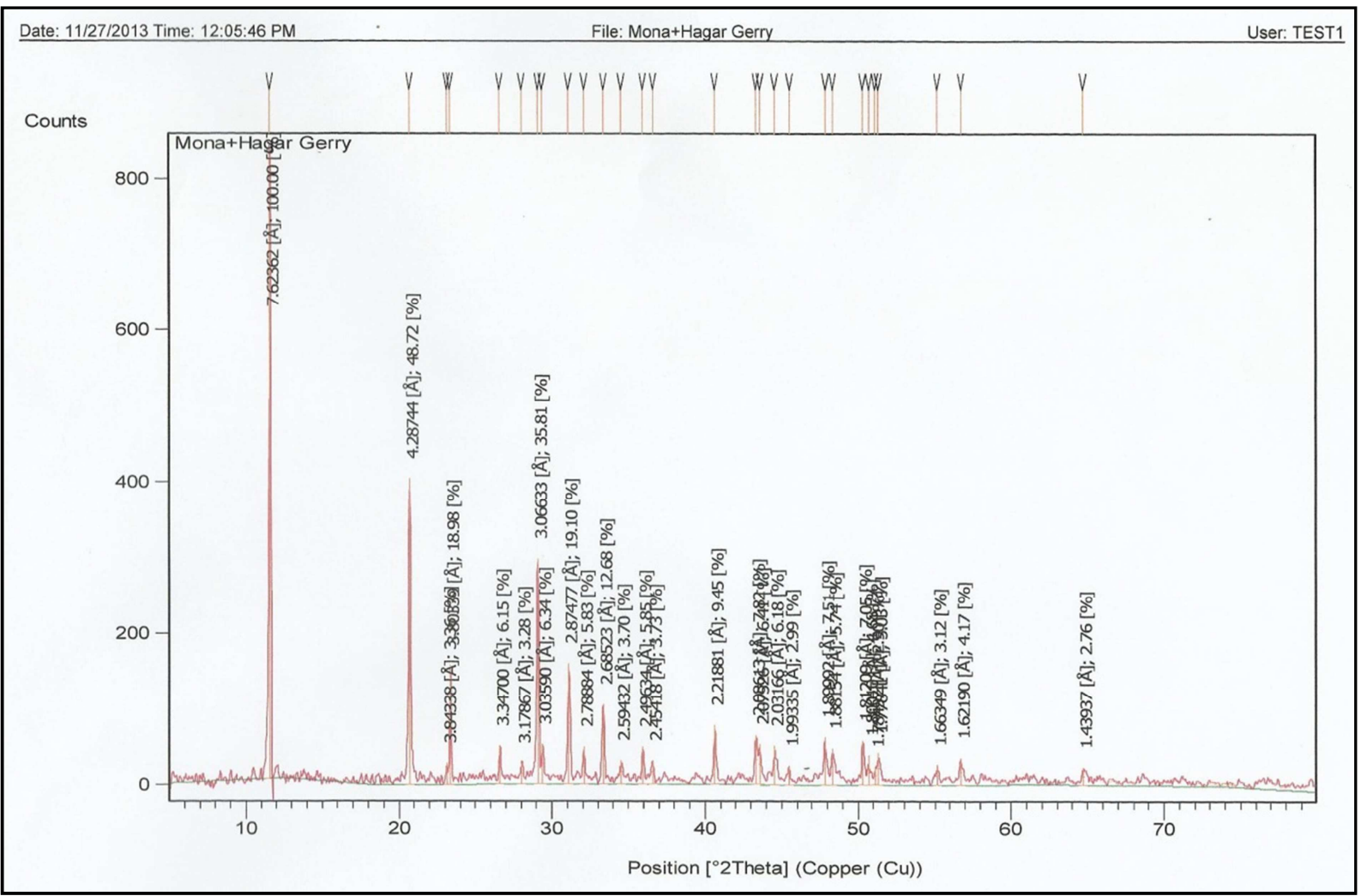

Figure 7. Shows the XRD analysis pattern for a mortar's sample from the limestone' ruins 

Site - Atfiyah - Egypt and Its Microbiological Effect

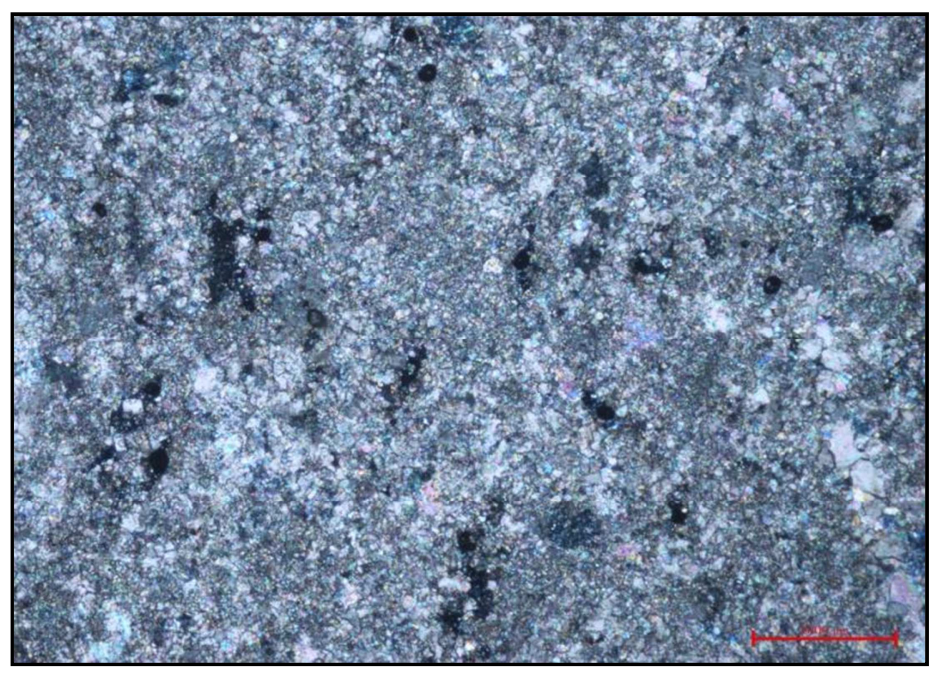

Figure 8. Shows the polarizing microscope examination for a mortar's sample from the limestone' ruins.

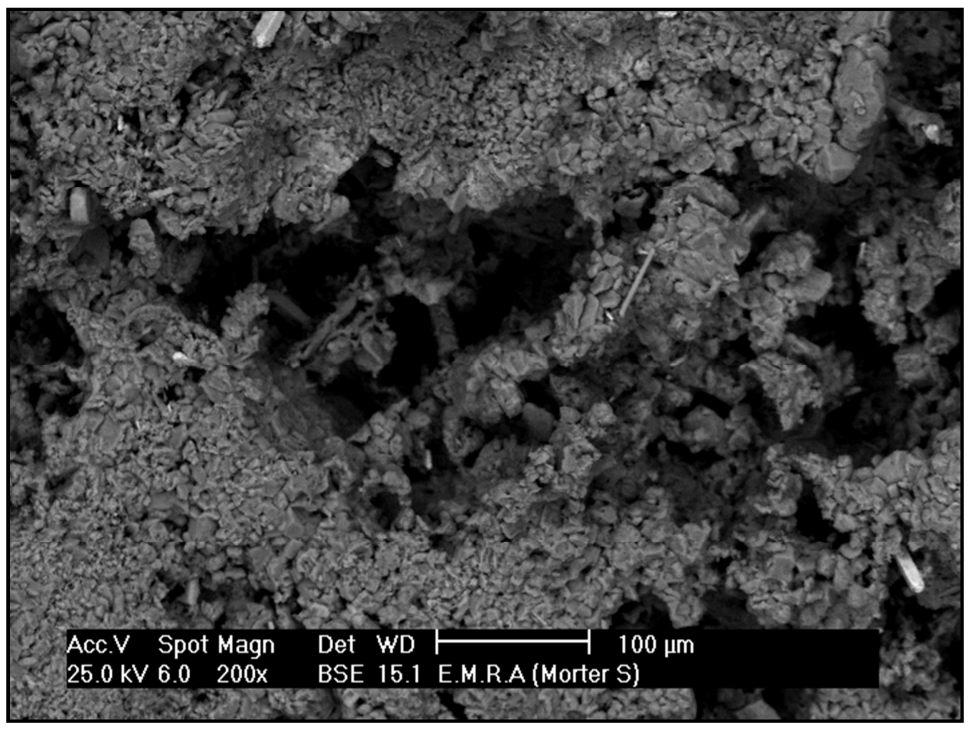

Figure 9. Shows the SEM examination for a mortar's sample from the limestone' ruins.

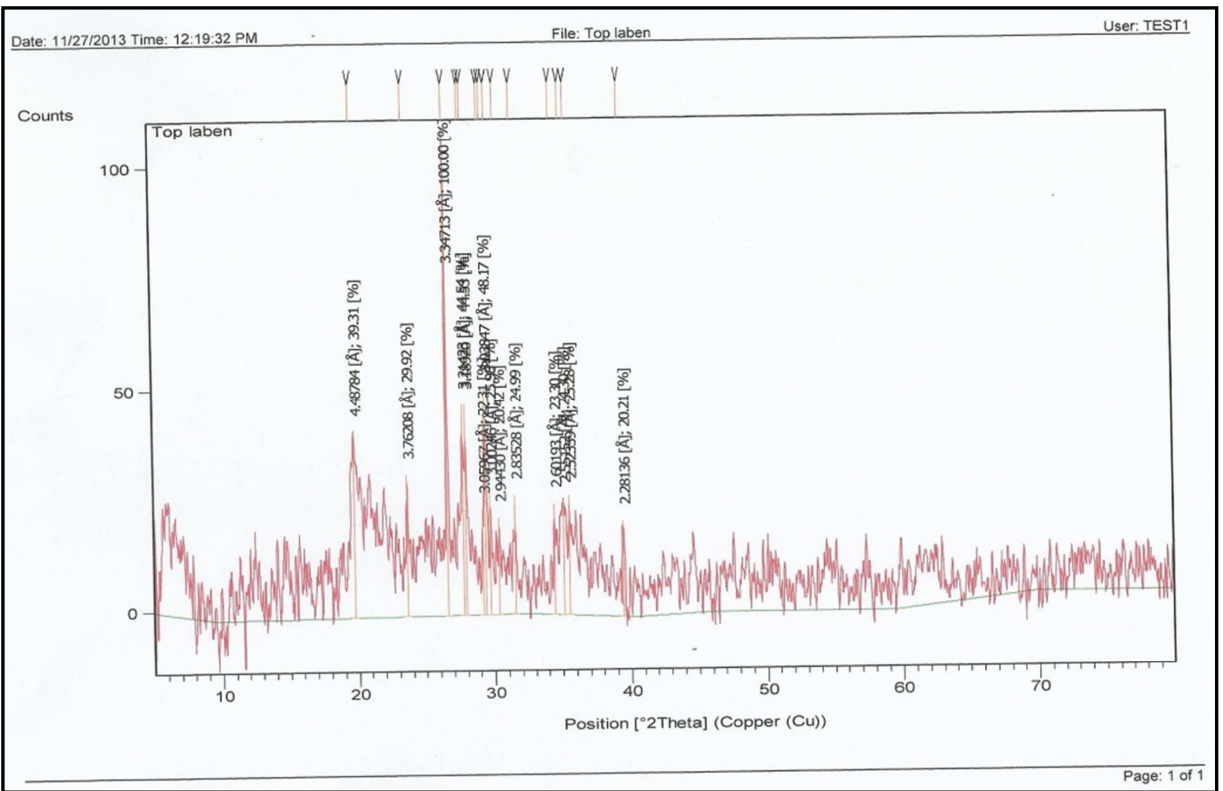

Figure 10. Shows the XRD analysis pattern for a sample of mud bricks ruins. 


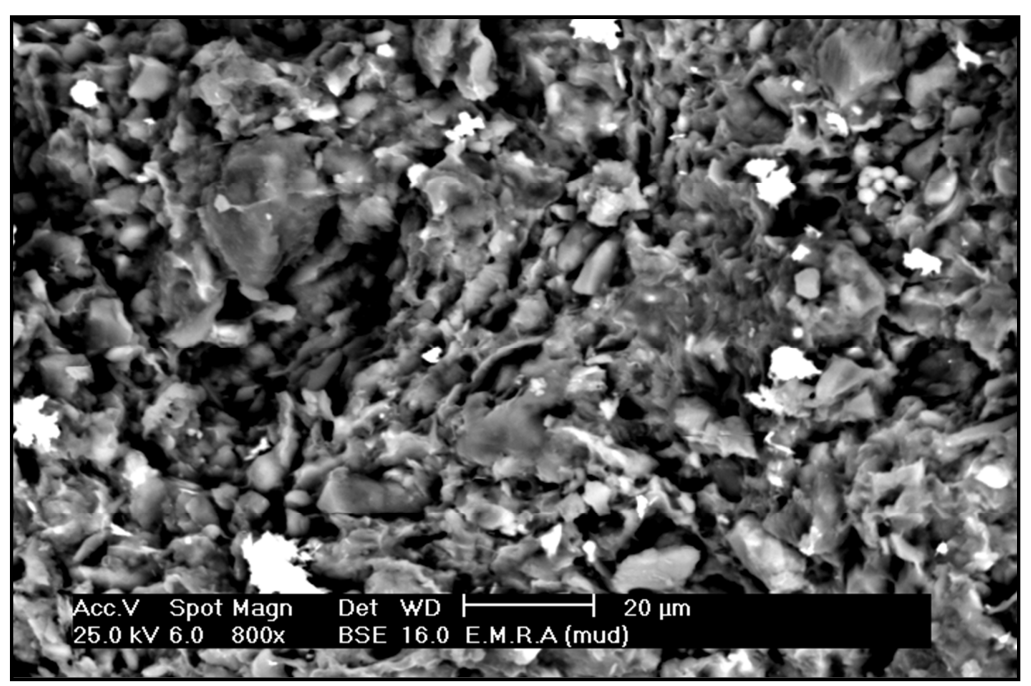

Figure 11. Shows the SEM examination for the mud bricks ' sample (800X).

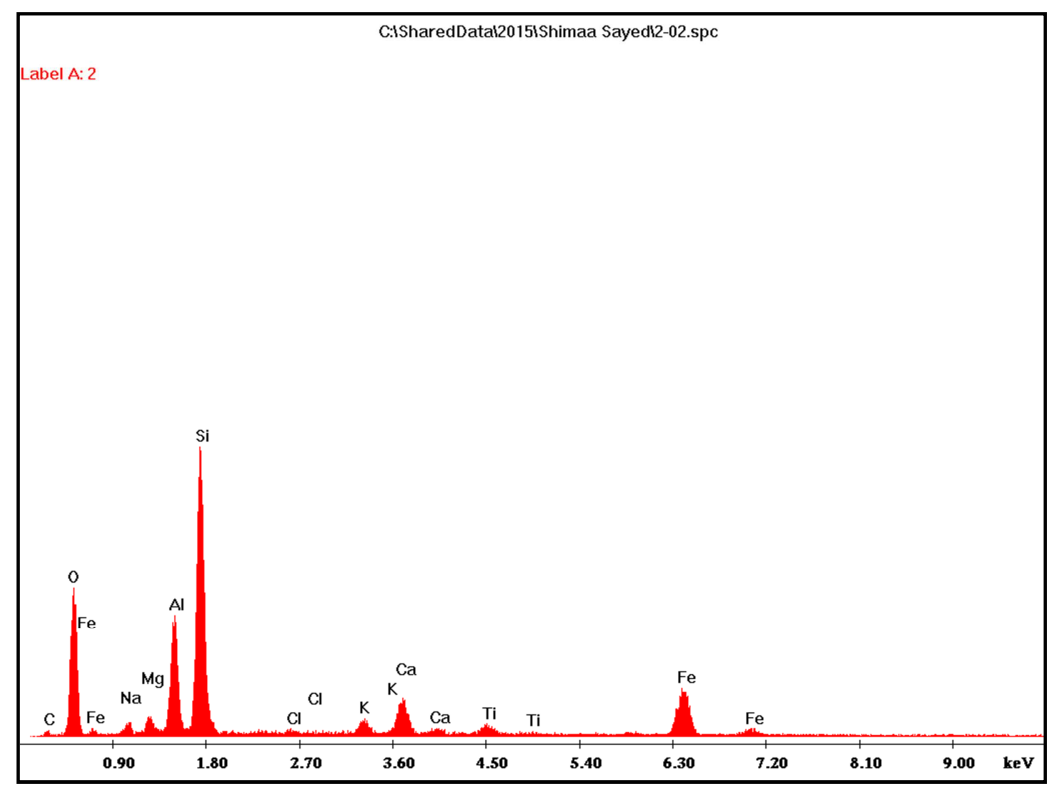

Figure 12. Shows the EDAX analysis of the mud bricks' sample.

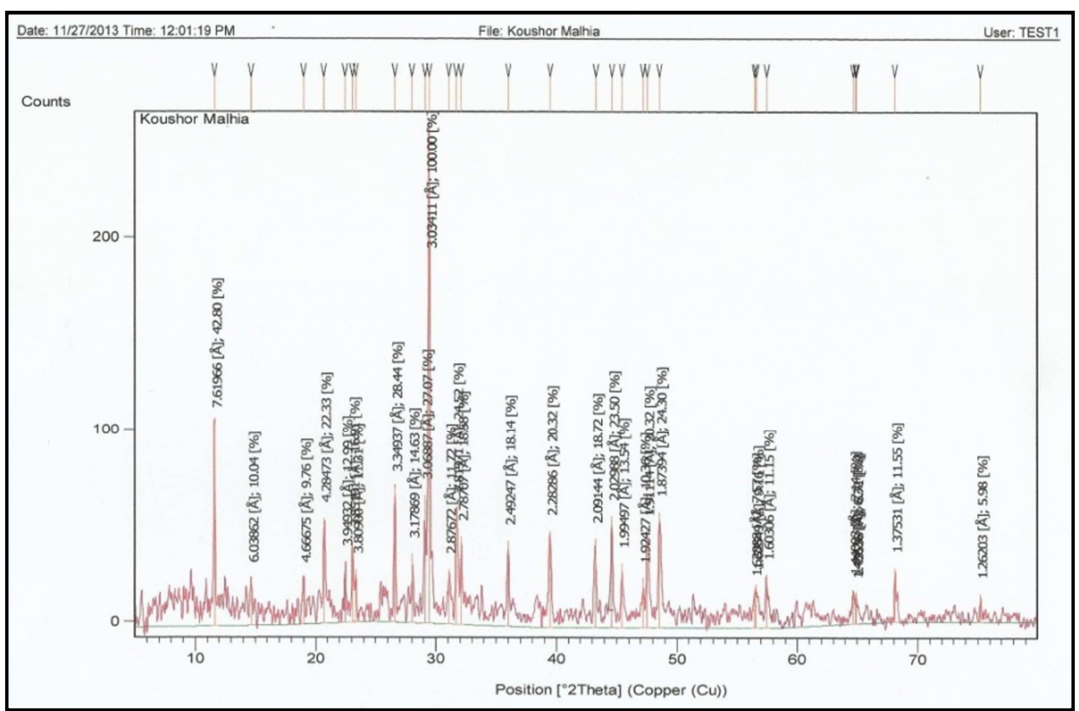

Figure 13. Shows the XRD analysis pattern for a sample of the salts flakes. 

Site - Atfiyah - Egypt and Its Microbiological Effect

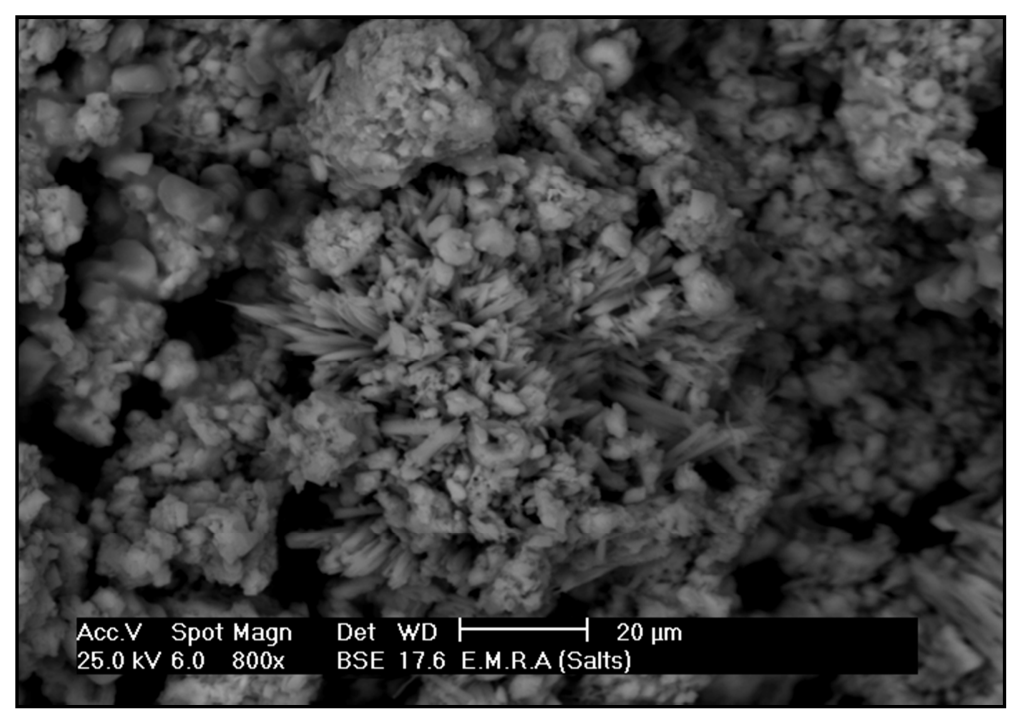

Figure 14. Shows the examination of the salts flakes ' sample with SEM (800X).

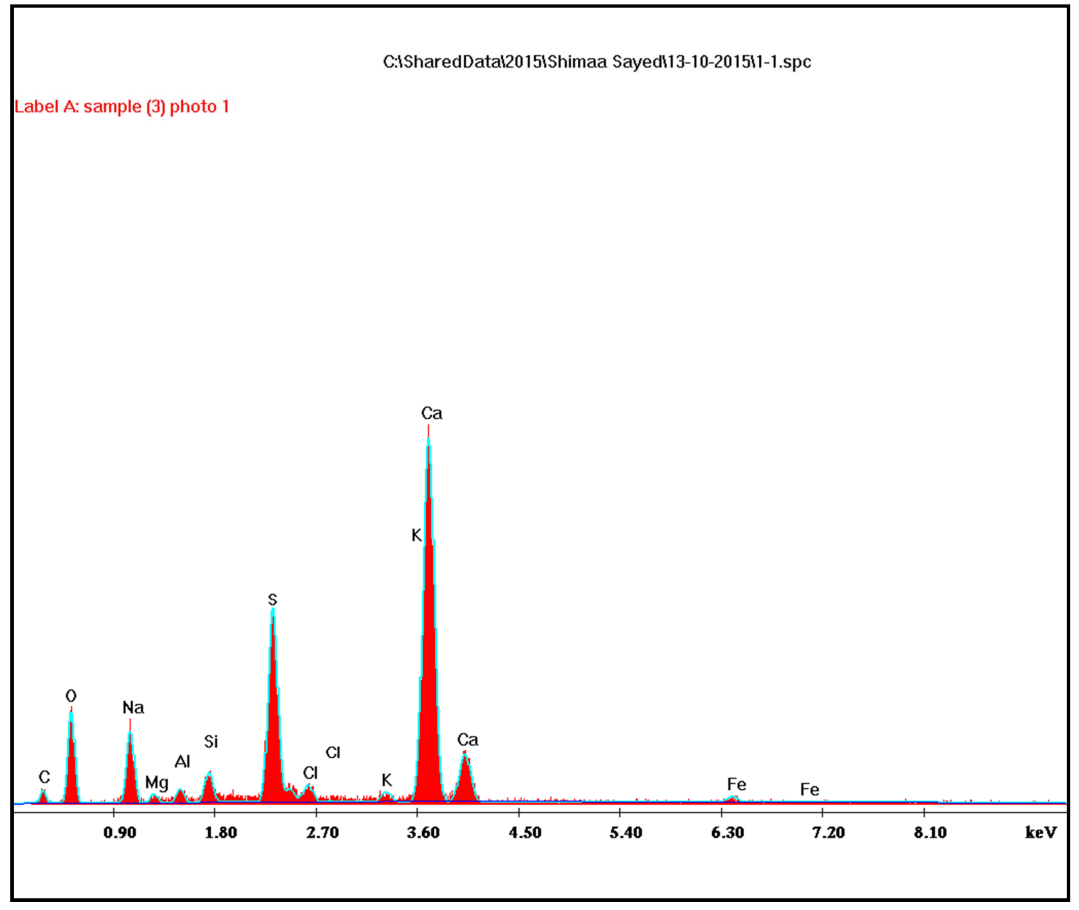

Figure 15. Shows the EDAX analysis of the salts flakes 'sample.

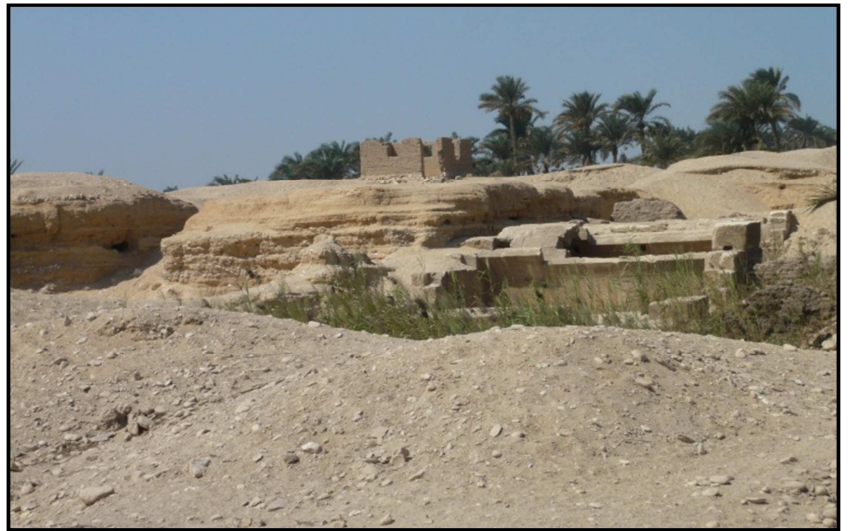

Figure 16. Shows an overview of Sarabium's archaeological site.

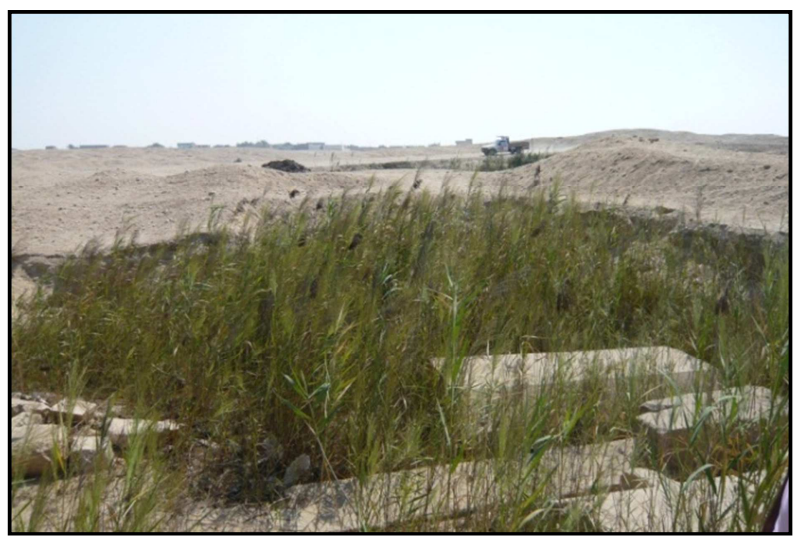

Figure 17. Shows the wide growth of weeds in limestone' coffins area in the site. 


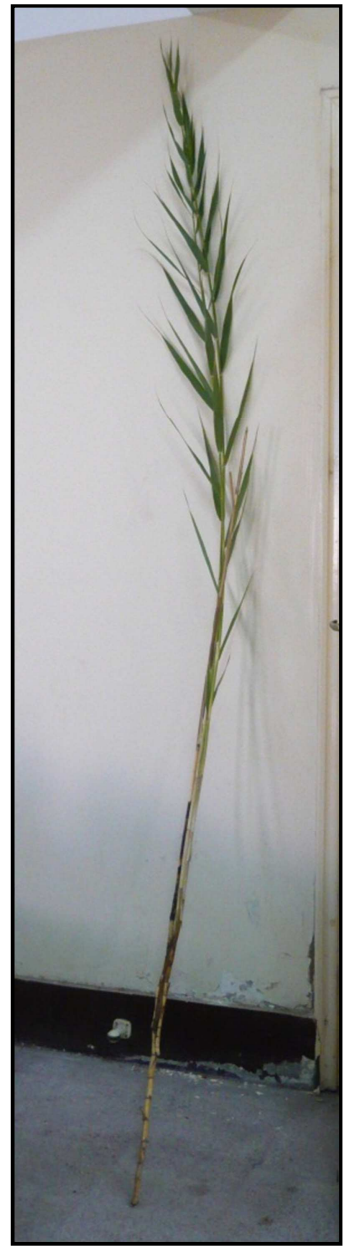

Figure 18. Shows the taken weeds' sample from the study site.

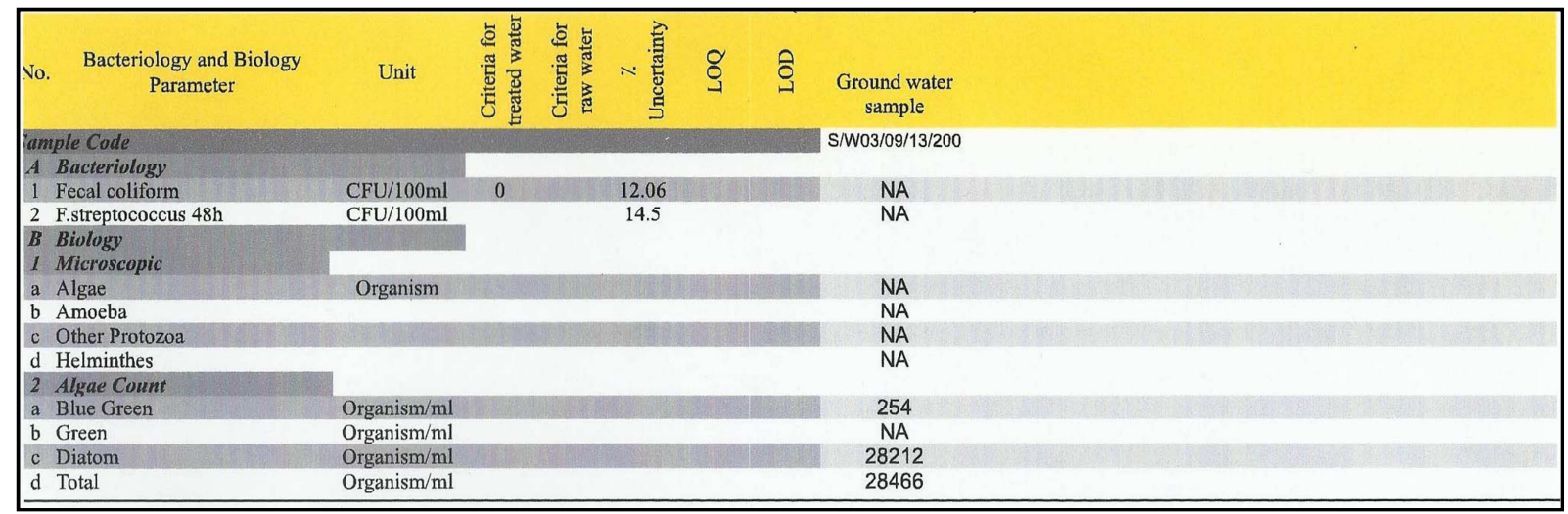

Figure 19. Shows the Microbiological analysis of the groundwater's sample.

\section{Results and Discussion}

- The groundwater's type in Atfiyah's Sarabium Archaeological site is Agriculture waste water due to the existence of sulphates and chlorides with high percentages, also the existence of coliform bacteria which live in the wet soils with high contamination, site is very near to the fields (100 meter far approx.) and the site is lower than the surrounding area, the agriculture waste water aggregates in the most lower point in the archaeological site (limestone' coffins).

- The limestone's sample contains calcite (Calcium carbonates) (the main component with $70 \%$ ), hydrous calcium sulphates (8\%), quartz (Silicon dioxide 9\%) and sodium chloride $13 \%$ ), and the examination with scanning electron microscope shows the weakness of the surface.

- The source of the high percentage of salts in the limestone's sample (Sodium chloride 13\% and hydrous 
calcium sulphates $8 \%$ ) is the agriculture waste water in the site which rises in the stone with the capillary system.

- The EDAX sample's analysis shows the existence of the followed elements ( $\mathrm{Ca}, \mathrm{O}, \mathrm{Cl}, \mathrm{Na}, \mathrm{S}$ and $\mathrm{Si}$ ) which confirms the XRD's sample analysis results.

- The analysis of the limestone ruins' mortar with XRD shows that it is a gypsum mortar and its components are gypsum (Hydrous calcium sulphates) $(39.78 \%)$, calcite (Calcium carbonates) (29.23\%), quartz (5\%), hematite (Ferrous oxide) (10.4\%), halite (Sodium chloride) $(15.59 \%)$, the existence of halite salt with high percentage due to the ground water existence in the site and rising of it in the wall by the capillary system.

- The polarizing microscope examination of the mortar shows the existence of gypsum, calcite, quartz, halite in the sample which confirms the XRD analysis's result of the same sample.

- The Scanning Electron Microscope (SEM) examination of the mortar's sample shows the weakness of the mortar and the high existence of salts (Halite) inside it in the needle's form.

- The mud bricks ' sample contains mainly Quartz (45.9\%), Calcite (22.12\%), Albite (20.45\%) and Halite (11.48\%).

- The examination of the mud bricks ' sample with SEM shows that mud bricks are very weak in the site because of the high percentage of quartz in them and the wide growth of weeds which penetrate deeply in mud bricks walls ruins and destroy them.

- The elemental analysis of mud bricks' sample with EDAX confirms the XRD's analysis.

- The analysis of salts flakes ' sample with XRay Diffraction (XRD) shows that the main component is calcite (51\%), Gypsum (22\%), Quartz (9\%) and Halite $(13 \%)$, which means that the salts grown in the building material especially limestone ' ruins are Halite and Gypsum and their percentages $(13+22 \%=35 \%)$ from the whole sample components percentage), it returns to the agriculture waste water in the site.

- The examination of the salts flakes ' sample with SEM shows the needle form of the salts which means that they crystalized inside the building materials, they will make stress inside them and the result will be the loss of these building materials in the end.

- The elemental analysis of the salts flakes' sample with EDAX confirms the XRD's analysis.

- The existence of the agriculture waste water in the site causes the high growth of some weeds like Phragmites communis (Trin.)

- The identification of the Microbiological effect of the groundwater shows the existence of blue green algae (Cyanobacteria) and diatoms (Bacillariophyceae) in the water, the transmission and growth of these microorganisms in the limestone's coffins and ruins surface), the blue green algae and diatoms grow in the existence of sunlight to make photosynthesis.
- The organic activity of the algae consist biofilm which deforms the limestone's view by their stains, also the algae fix the carbon and provide a source of nutrition for heterotrophic microorganisms which may further degrade the stone 's surface (bio weathering of the stones) [2], Figure (20-27).

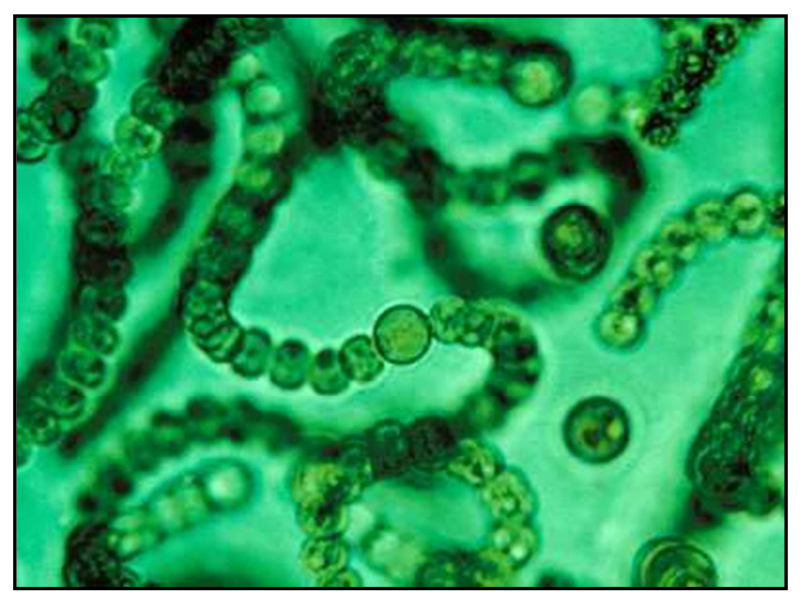

Figure 20. Shows the blue green algae under the microscope.

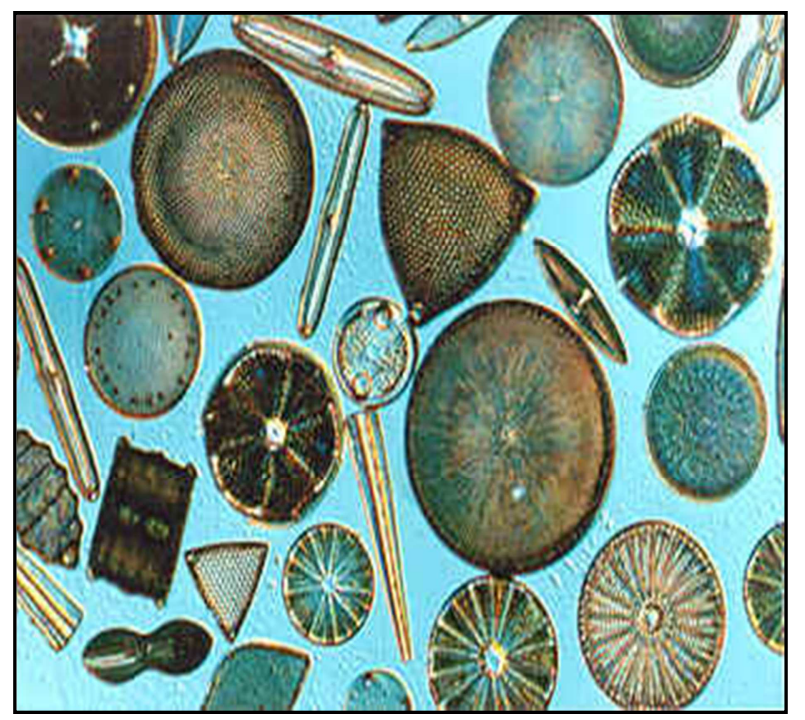

Figure 21. Shows the diatoms under the microscope.

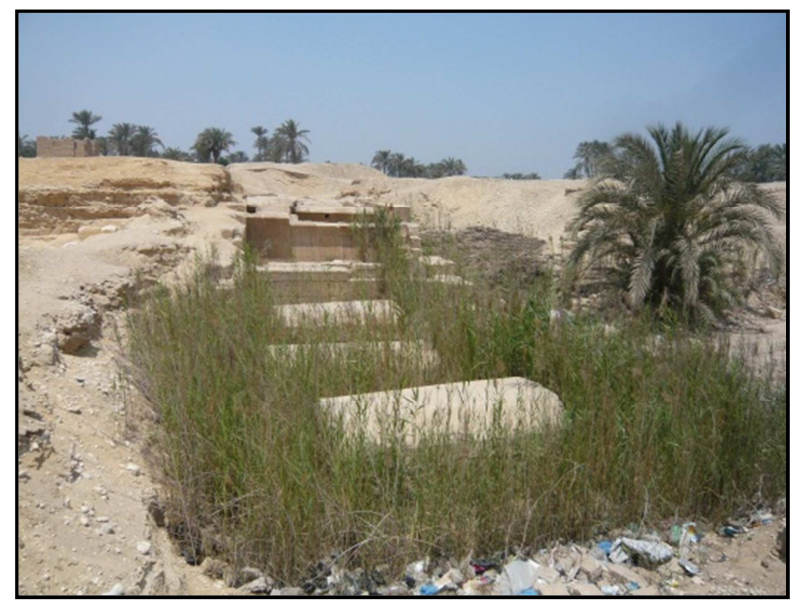

Figure 22. Shows Atfiyah's Sarabium archaeological site. 


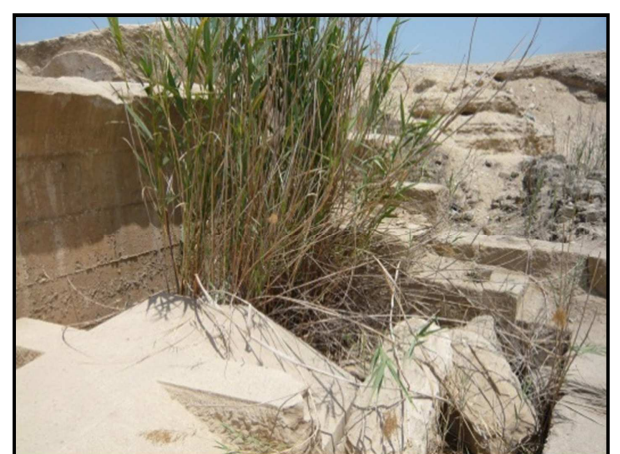

Figure 23. Shows the study area in the site (limestone' coffins and ruins).

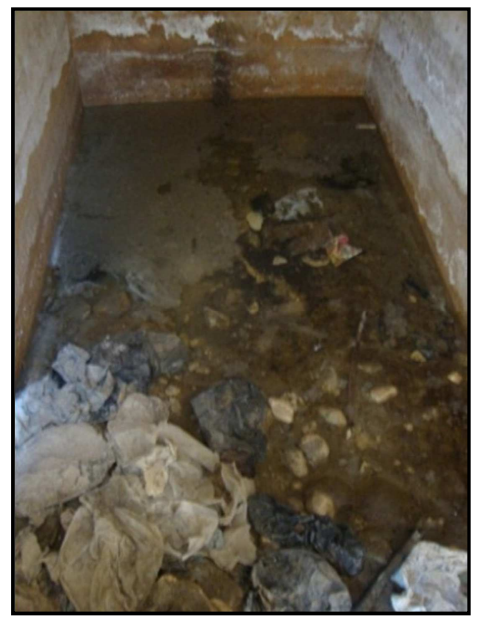

Figure 24. Shows the agriculture waste water aggregates in one of the limestone' coffins.

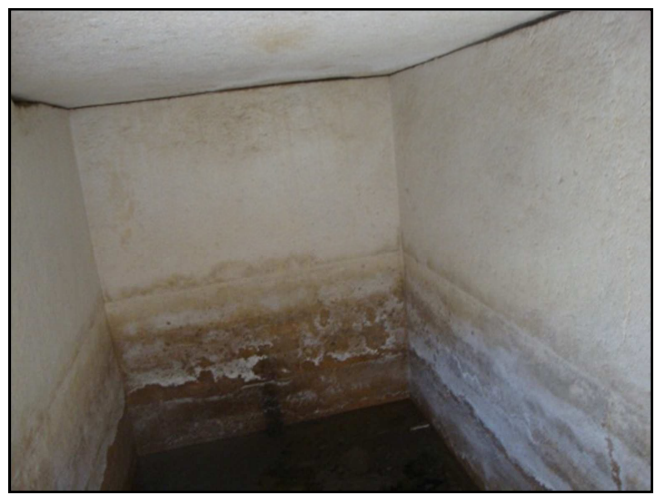

Figure 25. Shows growth of salts and algae inside the limestone's coffin.

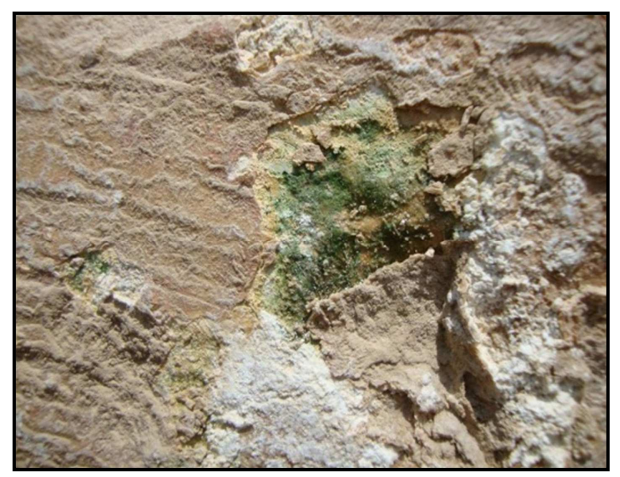

Figure 26. Shows the growth of algae on one of the limestone' ruins surface in the study area and staining of it.

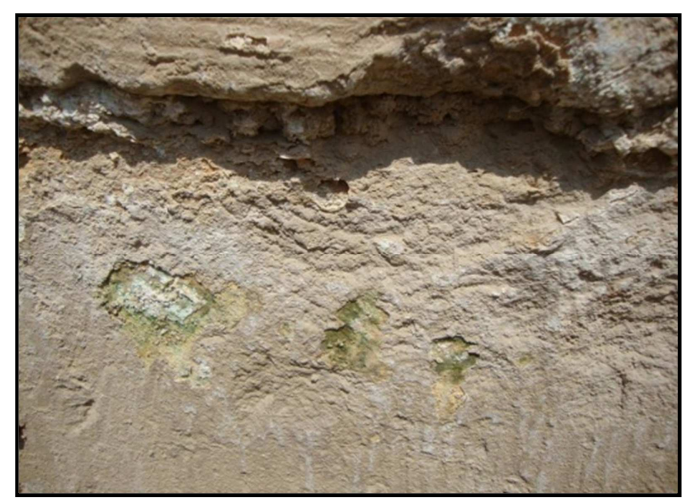

Figure 27. Shows the growth of algae on the external surface of one of the limestone' coffins.

\section{Conclusion}

The existence of groundwater in Atfiyah's Sarabium archaeological site causes Microorganisms and salts ' growth, the type of the groundwater is agriculture waste water and the resulted microorganisms' type from it (Blue green algae and diatoms) which grow widely on limestone' coffins and ruins surface, also, it causes the existence of salts (Sodium chloride and hydrous calcium sulphates) on the surface and inside the limestone. The high growth of weeds in the site also due to the existence of agricultural waste water.

\section{Acknowledgment}

To Central Laboratories of Water Analysis - Fayoum Drinking Water and Sanitation Company (FDWSC) Ministry of Housing and Utility - Egypt especially Chemist / Marwa Sayed Mahgoub for their great effort in the water sample 's analysis from the study site and the identification of microorganisms.

- Prof. Dr / Mohamed Abdel Hady Mohamed - Prof. of Restoration and Conservation - Faculty of Archaeology - Cairo University - Egypt.

- Prof. Dr / Hussein Fawzy Hussein AbouZainah - Prof. of Botany - Agricultural and Biological Research Division- National Research Centre - Egypt.

- Mr / Sabry Gaber- Pests and weeds management laboratory - Antiquities ' Researches and Conservation center - Project Sector - Ministry of Antiquities - Egypt.

- Atfiyah's Restoration Authority - Ministry of Antiquities - Egypt especially Conservator / Mohamed Abdel Ghany.

\section{References}

[1] Mission égypto-française d'Atfih, Atfih, la nécropole des vaches sacrées (mission 2008), Institut d' Egyptologie Francois Daumas, Universite Paul Valery, France, 2008.

[2] Nick A. Cutler, Heather A. Viles, Samin Ahmad, Stephen McCabe, Bernard J. Smith, Algal 'greening' and the conservation of stone heritage structures, Science of the Total Environment 442, (2013), P: 153. 
[3] Shaimaa Sayed Mohamed El-Sayed Mahgoub, "Evaluation of Wild and Domestic Trees and Plants Hazards, their Role in the Deterioration of Archaeological Buildings Ruins, Methods of Treatment and Assessment of these Hazards Applied on a Chosen Historical Building and Site", PhD thesis, Restoration department, Faculty of Archaeology, Cairo University, Egypt, 2015/2016.

[4] Rabea Radi Abdel Kader and Shaimaa Sayed Mohamed, "The study of ground water effect and risks on the safety of the Archaeological Islamic buildings in Egypt applied on Azabk El-Youssefi Madrasa", Built Heritage 2013 Monitoring Conservation Management, Italy, PP: 1212-1216.

[5] Honeyborne, B. D., "Weathering and decay of masonry "in" conservation of building and decorative stone", first publish, Butterworth Heinemann, Great Britain, 1990.

[6] Oliver, A., "Dampness in buildings", BSP publishers, 1998.
[7] Mitchell, R.,"The role of micro-organisms in the deterioration of atmospheric pollutants of stone used in historic buildings and monuments ", Harvard university, Division of engineering \&applied sciences, January 2001.

[8] Kumar, R., et al., "Biodeterioration of stone in tropical environments", the Getty conservation institute, 1999.

[9] Johnson, J. S., "Soluble salts and deterioration of archaeological materials", national park service, Washington, August 1998.

[10] Ismail, B.,"Environmental deterioration and conservation of monumental basalt, Egypt", Bull Enviro. Res. Vol 7, No. 1, Assiut.

[11] Charola, A. E., "Salts in the deterioration of porous materials "An overview, in JAIC 39, 2000. 